\title{
A new record of the Axiid shrimp Balssaxius habereri (Balss, 1913) (Crustacea: Decapoda: Axiidea) in Korean waters
}

\author{
Jung Nyun Kim ${ }^{1 *}$, Jung Hwa Choi ${ }^{2}$, Yang Jae $\mathrm{Im}^{1}$ and Hyun-su Jo ${ }^{3}$
}

\begin{abstract}
Balssaxius habereri (Balss, 1903) has been newly reported in Korean waters. This species was previously known from the Pacific coast of northern Japan, Korea Strait, Yellow Sea, and Japanese coast of the East Sea. Specimens were collected from western Jeju Island using otter trawls at depths of 65-85 m. Regarding Korean axiid shrimps, a single species, Boasaxius princeps (Boas, 1880), previously known as Axiopsis princeps in Korea, has been recorded. B. habereri is easily distinguished from B. princeps as it does not have tufts of setae on its body and males do not have the first pleopod. Morphological descriptions and color photos of the specimens are provided.
\end{abstract}

Keywords: Balssaxius habereri, Axiidae, Korea, Distribution record

\section{Background}

The family Axiidae currently includes 193 species of 62 genera globally (Poore 2015). They can be morphologically characterized by the combination of a prominent rostrum ending in an acute tip, lacking the linea thalassinica, similar laminar rami on the second to fifth pleopods, and an oval uropodal endopod with a distal flap. They usually occur worldwide in temperate to tropical regions from intertidal habitats to water depths of more than 2000 m (Dworschak 2015). In Korea, only a single species, Boasaxius princeps (Boas, 1880), previously known as Axiopsis princeps, has been reported in the family to date (Kim and Kim 1997). During a taxonomic study on decapod crustaceans in Korean waters, three specimens of the axiid shrimp Balssaxius habereri (Balss, 1913) were collected from western Jeju Island, at depths of $65-85 \mathrm{~m}$ by a bottom otter trawl mounted on R/V Tamgu 1 and R/V Tamgu 20 of the National Institute of Fisheries Science, Korea. B. habereri was originally described by Balss (1913) as Axius habereri from Sagami Bay in the central Pacific coast of Japan. Subsequently, the species has been recorded from the Pacific coast of northern Japan, Korean Strait, Yellow Sea, and Japanese

\footnotetext{
* Correspondence: crangonk@korea.kr

${ }^{1}$ West Sea Fisheries Research Institute, National Institute of Fisheries Science, Incheon 22383, South Korea

Full list of author information is available at the end of the article
}

coast of the East Sea. The present material is the first record of $B$. habereri in Korea. The aim of the present report was to provide morphological descriptions and color photographs of this species.

\section{Methods}

The species were collected using sampling gear comprising bottom otter trawls (mesh size at the cod end $0.98 \times$ $0.98 \mathrm{~mm}$ ). A net with otter boards was towed during the daytime for 30-60 min at a mean 3.4 knots. All the samples collected were frozen onboard shortly after capture and maintained at $-80{ }^{\circ} \mathrm{C}$ until laboratory identification. Before identification, samples were photographed and preserved in 70-90 \% ethyl alcohol.

Carapace length (CL), from the posterior margin of the orbit to the posterior middorsal margin of the carapace, was used to indicate the size of the specimens. Terminology mainly followed Sakai (2011).

The examined specimens have been deposited in the National Institute of Fisheries Science, Korea (NIFS).

\section{Results and discussion \\ Family Axiidae Huxley, 1879 \\ Genus Balssaxius Sakai, 2011 \\ (New Korean name: Nam-bang-ga-jae-a-jae-bi-sok) \\ Balssaxius habereri (Balss, 1913) \\ (Figure 1)}




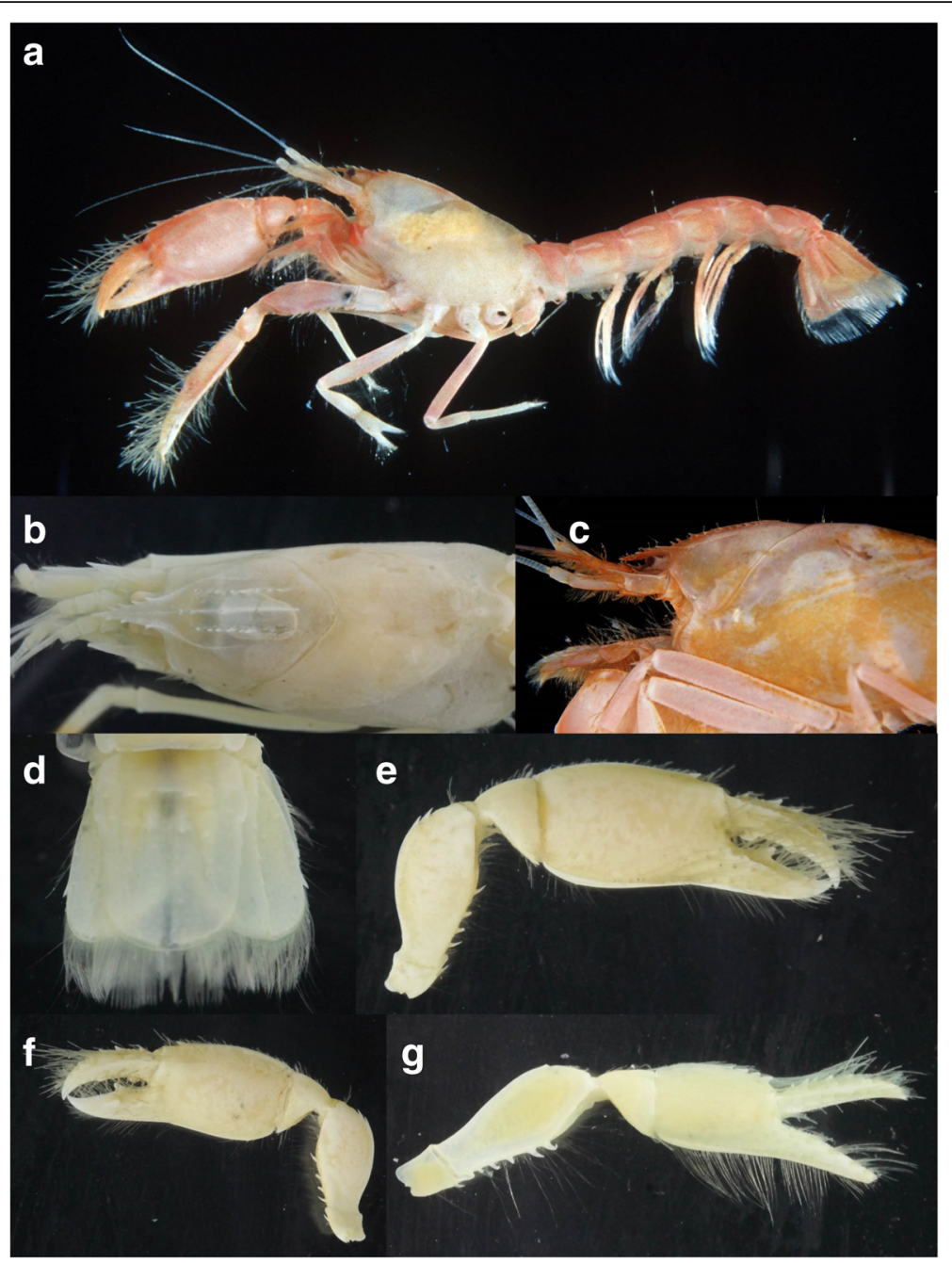

Fig. 1 Balssaxius habereri (Balss, 1913). a, b, d, g, male (CL $18.0 \mathrm{~mm}$ ) from western Jeju Island; c, e, f, male (CL 14.1 mm) from west-northwestern Jeju Island. a entire animal, lateral; b carapace, cephalic, and thoracic appendages, dorsal; c same, lateral; d tail fan, dorsal; e major cheliped, lateral; f same, mesial; $\mathbf{g}$ minor cheliped, lateral

(New Korean name: Nam-bang-ga-jae-a-jae-bi)

Axius habereri Balss, 1913, p. 238 (type locality: Sagami Bay, Japan); 1914, p. 85, text-figs 46, 47; Yokoya 1933, p. 49.

Axiopsis (Axiopsis) habereri: De Man, 1925, p. 70; Miyake 1982, p. 89, pl. 30, fig. 3.

Calocarides habereri: Sakai and de Saint Laurent, 1989, p. 83.

Balssaxius habereri: Sakai, 2011, p. 74, fig. 13A, B.

\section{Material examined}

Jejudo: 1 ô (CL $18.0 \mathrm{~mm}$ ) (western Jeju Island, 32 59.9' $\mathrm{N} 124^{\circ} 26.0^{\prime} \mathrm{E}, 65 \mathrm{~m}$, otter trawl, Tamgu 1: March 14, 2002); 1 (CL $14.1 \mathrm{~mm}$ ) (west-northwestern Jeju Island, $33^{\circ} 46.1^{\prime} \mathrm{N} 124^{\circ} 49.4^{\prime}$ E, $85 \mathrm{~m}$, otter trawl, Tamgu 20:
April 8, 2009); 1 ㅇ (CL $19.2 \mathrm{~mm}$ ) (west-southwestern Jeju Island, $32^{\circ} 5.4^{\prime} \mathrm{N} 125^{\circ} 15.5^{\prime} \mathrm{E}, 76 \mathrm{~m}$, otter trawl, Tamgu 20: March 25, 2015).

\section{Description}

Rostrum (Fig. 1a-c) acutely triangular, reaching slightly beyond first segment of antennular peduncle or reaching midlength of second segment, concave dorsally, lateral margin with four small teeth. Carapace (Fig. 1a-c) without supraocular spine; gastric median carina with three teeth anteriorly; submedian carina distinct, with row of 8-10 teeth; lateral carina smooth, continuous lateral margin of rostrum; gastric region with sparse short setae; cervical groove distinct and deep; postcervical carina and pair of posterior protrusions present. Pleonal pleura all rounded marginally. Telson (Fig. 1d) longer than wide; bearing proximal lobe with spine posteriorly, 
followed by two denticles on lateral margin; dorsal surface with median groove, one pair of proximal submedian spines, two pairs of lateral spines; posterior margin rounded posteriorly, with small median tooth in males, without median tooth in female. Eyestalk (Fig. 1b, c) falling slightly short of midlength of rostrum. Antenna with elongate scaphocerite, reaching slightly beyond midlength of penultimate segment of antennular peduncle. Cheliped unequal. Major cheliped (Fig. 1e, f) with ischium bearing one spine on ventrodistal margin; merus with two subdistal spines on dorsal margin and four ventral spines; chela compressed laterally, with one or two subdistal spines on dorsal margin of palm; dactylus shorter than palm, laterally denticulate, with row of several spines on dorsal margin. Minor cheliped (Fig. 1g) with one ventrodistal spine on ischium; merus with one dorsodistal spine, ventral margin with five spines; palm slightly shorter than dactylus, with four anterior dorsal spines. Uropodal endopod (Fig. 1d) with longitudinal median carina bearing eight teeth, lateral margin with one or two subdistal spines; exopod with transverse suture bearing row of 10 small teeth; lateral margin with five to seven teeth including posterolateral tooth and movable spinule, mesial to base of posterolateral tooth.

\section{Coloration}

Entirely pale orange (Fig. 1a).

\section{Distribution}

Korea, Japan; 65-160 m.

\section{Remarks}

A. habereri originally described by Balss (1913) was included in the genus Axiopsis by De Man (1925) and later in Calocarides by Sakai and de Saint Laurent (1989). However, it does not belong to Calocarides due to the presence of sharp postcervical carina on the carapace. In contrast, the carapace of the type species of Calocarides, Calocarides coronatus (Trybom, 1904), bears no postcervical carina. Sakai (2011) established the new genus Balssaxius for the present species.

The present material generally agrees with the original description by Balss (1913) and the subsequent description by Sakai (2011), who examined the female lectotype deposited in Zoologische Staatssammlung in Munich. However, a few minor discrepancies, which could fall within the range of intraspecific variation, are apparent: the minor cheliped with merus has one dorsodistal and five ventral spines in the present specimens, whereas the type specimens have two dorsodistal and six ventral spines.

\section{Conclusions}

$B$. habereri is easily distinguished from B. princeps since it lacks tufts of setae and the first pleopod is lacking in males. The present species rarely occurred near Jeju Island in sandy mud bottom habitats, whereas B. princeps is distributed from Busan to Dokdo Island in rocky bottom habitats. Although this species is endemic in East Asian waters, i.e. Korea Strait, Yellow Sea, Japanese coast of the East Sea, and Pacific coast of Japan, it is never reported in Korean waters.

\section{Acknowledgements}

This research was funded by the National Institute of Fisheries Science, Korea (R2016032).

\section{Authors' contributions}

JNK and JHC carried out the sampling and identification the species. JNK participated in drafted the manuscript. YJI and HJ conceived of the study and participated in its design and coordination. All authors read and approved the final manuscript.

\section{Competing interests}

The authors declare that they have no competing interests.

\section{Author details}

${ }^{1}$ West Sea Fisheries Research Institute, National Institute of Fisheries Science, Incheon 22383, South Korea. ${ }^{2}$ Southeast Sea Fisheries Research Institute, National Institute of Fisheries Science, Tongyeong 53085, South Korea. ${ }^{3}$ Department of Marine Science and Production, Kunsan National University, Kunsan 54150, South Korea.

Received: 17 November 2015 Accepted: 9 June 2016

Published online: 09 November 2016

\section{References}

Balss H. Ostasiatische Decapoden. I. Die Galatheidae und Paguridae, in Beiträge zur Naturgeschichte Ostasiens, herausgegeben von Pr. F. Doflein. Abhand K Bayerischen Akad Wiss Math Physik Klasse. 1913;Suppl 2:1-85.

De Man JG. The Decapoda of the Siboga Expedition. Part VI. The Axiidae collected by the Siboga-Expedition. Siboga Exped. 1925:39a5:1-127.

Dworschak PC. Methods collecting Axiidea and Gebiidea (Decapoda): a review. Ann Naturhist Mus Wien B. 2015;117:5-21.

Kim HS, Kim W. Order Decapoda. In: The Korean Society of Systematic Zoology, editor. List of animals in Korea (excluding insects). Seoul: Academy Publ. Co; 1997. p. 212-23.

Miyake S. Japanese crustacean decapods and stomatopods in color. Vol. I. Macrura, Anomura and Stomatopoda. 1st ed. Osaka: Hoikusha, JP; 1982

Poore G. 2015. Axiidea de Saint Laurent, 1979. World Register of Marine Species at http://www.marinespecies.org/aphia.php?p=taxdetails\&id=477324 on 2015-09-30.

Sakai K. Axioidea of the world and a reconsideration of the Callianassoidea (Decapoda, Thalassinidea, Callianassida). Leiden: Brill; 2011.

Sakai K and de Saint Laurent M. A check list of Axiidae (Decapoda, Crustacea, Thalassinidea, Anomura), with remarks and in addition descriptions of one new subfamily, eleven new genera and two new species. Tokushima: Naturalists Publ Tokushima Biol Lab Shikoku Women's Univ; 1989. 3:1-104.

Yokoya Y. On the distribution of decapod crustaceans inhabiting the continental shelf around Japan, chiefly based upon the materials collected by S.S. SôyôMaru, during the years 1923-1930. J Coll Agr Toyko Imp Univ. 1933;12:1-222. 